\title{
Review
}

\section{Helix and Drugs: Snails for Western Health Care From Antiquity to the Present}

\section{Bruno Bonnemain}

\author{
58 rue du Maréchal Joffre, 77270, Villeparisis, France
}

\begin{abstract}
The land helix, or snail, has been used in medicine since antiquity and prepared according to several formulations. This historical report traces the understanding of their properties from the time of Hippocrates, who proposed the use of snail mucus against protoccle and Pliny who thought that the snail increased the speed of delivery and was "a sovereign remedy to treat pain related to burns, abscesses and other wounds", Galien recommended snails against hydrops foetails. In the 18th century, various snail "preparations" were also recommended for external use with dermatological disorders and internally for symptoms associated with tuberculosis and nephritis. Surprisingly, the 19th century saw a renewed interest in the pharmaceutical and medical use of snails with numerous indications for snail preparations. This interest in snails did not stop at the end of the 19th century. The 1945 edition of Dorvault devotes an entire paragraph to snails, indicating that the therapeutic usage of snails was still alive at that time. Recently the FDA has also shown an interest in snails. Ziconotide (SNXIII), a synthetic peptide coming from snail venom, has been under FDA review since 1999. Pre-clinical and clinical studies of this new drug are promising.
\end{abstract}

Keywords: Snail - helix - medical history

\section{Ancient Beginnings of Snails and Potential Application to CAM}

The land helix, or snail, has been used in medicine since antiquity and prepared according to several formulations. The therapeutic properties of snails were thought to come from their holy strength. 'Associated with femininity and fertility, curative properties are given to snails to treat associated diseases' (1). Hippocrates proposed snail mucus against protocoele. Celse considered crude snail, i.e. snail crushed with its shell, as a healing substance. Boiled, it is supposed to have emollient properties. Pliny thought that snail increased the speed of delivery. Reduced to a pulp, 'it is a sovereign remedy to treat pain related to burns, abscesses and other wounds'. Pliny also recommended snails for nosebleed and stomach pain, and many other pathological conditions: 'female scrofula can be cured with very dry and peeled old snails. To patients with stomach pains, one must prescribe snails that were boiled

For reprints and all correspondence: Bruno Bonnemain, 58 rue du Maréchal Joffre, 77270, Villeparisis, France. E-mail: bruno.bonnemain@wanadoo.fr and grilled over a coal fire, and should be eaten with wine. Snails from Africa are the best, but they must be prepared in an uneven number. Those who spit up blood feel much better if they drink snails. Eating snails was prescribed for individuals suffering from vertigo, fainting fits, and fits of madness. The snails should be crushed in the shell and heated with wine' (2). Pliny finally directed: 'arrows, darts that have to be extracted from the body are attracted outside by applying a rat or a lizard that is cut down the middle. Snails which are attached in groups on the leaves of trees are crushed, as well as snails in their shells, and applied for the same reason to the wound' (3). Galien recommended snails against hydrops fetalis. Antiquity expanded the idea that the snail has an instinctive knowledge of some remedies: 'A snail', said Ambrose, 'when eating snake intestines and feels the penetration of poison, cures itself with oregano and when a snail is in a swamp, it is able to find the appropriate antidote and knows the power of saving herbs' (4).

Closer to us, Ambroise Paré recommended snails against anthrax (5). Snail water is also present in the Universal Pharmacopoeia, written by Lemery in 1738, in France: 'One leaves snails in their shells, washes them, and then crushes

(C) The Author (2005). Published by Oxford University Press. All rights reserved.

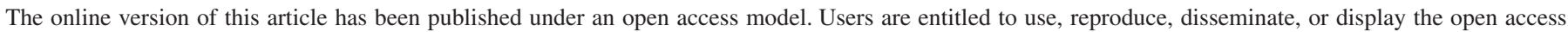

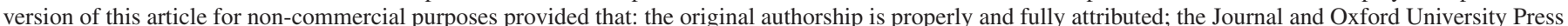

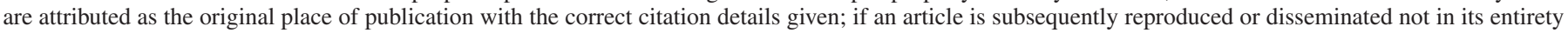
but only in part or as a derivative work this must be clearly indicated. For commercial re-use, please contact journals.permissions@ oupjournals.org 
them in a marble mortar. They are placed in a large glass jar, positioned on a bain-marie, into which the fresh milk of a female donkey is poured. The whole is mixed well with a wooden spatula, and then left for digestion for $12 \mathrm{~h}$ before it is distilled. The resulting distilled water is exposed to the sun for several days in a glass bottle, and then kept in the bottle. This is a hydrator, and is refreshing, useful for skin redness, and can be used to clean up one's face... It can also be used internally for the spasms of spitting blood accompanying tuberculosis, and for the urine ardour of nephritis. The dosage is between one and six ounces' (6).

\section{9th Century: Pharmaceutical and Medical use of Snails}

The 19th century saw a renewed interest in the pharmaceutical and medical use of snails. One can see this more specifically with the work of George Tarenne who, in 1808, published a book on snails and their ability to cure hernias (7). Speaking of snail juice, Tarenne indicated that 'its viscosity, its contraction or astringent strength, and its capability for reproduction allowed me immediately to suppose that it would close hernia openings'. In 1817, the New Natural History Dictionary stated that 'one can pick up snails for use in Medicine and are recommended as a broth for the throat and a smoother mixture is good for females and can be used to keep the surface of the skin smooth and brilliant.' At that time, snails were stringed as rosaries and were used as shop signs for pharmacies. The work of Figuier in 1840 is also worthy of note. Quoting E. Soubeiran, he wrote, 'Snails contain an animalized mucilage, although not well known from the chemical point of view, it is used with confidence by some people for chest diseases; sometimes, one prescribes crude snails. In this form, it is a disgusting remedy' (8). Figuier also indicated that several physicians had therapeutic experience with snails: Chrestien, Pourché, Legrand, Simon and Flin all used the remedy for tuberculosis. The book describes useful pharmaceutical formulations: snails, sugar, tablets, syrup, snail paste and snail chocolate. These formulations were applied orally and indicated for resistant colds, tuberculosis of the first and second degrees, acute and chronic chest ailments and intestinal irritations. Snail ointment is only for external use to treat chapping and efflorescence of a sore. Figuier mentions the properties of hélicine, a transparent yellow oil, extracted from Helix pomatia but also from 'all big species of snails' (8). Later, Dr Revnes confirmed in 1874 'a patient having reached the last stage of marasmus can easily digest several dozen crude snails, even though his lazy and impaired stomach can barely support donkey milk' (5).

The 1877 edition of Dorvault (a pharmaceutical reference book in France at that time) also mentioned several products based on snails: snail paste with donkey milk, Quelquejeu snail paste, Figuier or de Mure snail pectoral paste, Figuier or de Mure snail syrup, Figuier snail pectoral syrup, as well as Baron-Barthelemy snail pectoral paste. Baron-Barthelemy, a pharmacist in Beziers (Hérault, France), published a report about the pharmaceutical formulations based on helicine that were approved for the 1855 Universal Exhibit. In this report, Baron-Barthelemy discussed the therapeutic properties of helicine: 'The opinion of the famous pharmacologist Barbier seems essential for us on the subject. It is always observed, he said, that in the slow inflammation of pulmonary organs, snail preparations have sometimes decreased the morbid activity, stopped its progression, and finally destroyed the disease' (10). Baron-Barthelemy listed the numerous indications of these snail preparations: 'They have been used with success against most inflammations, and especially against cold and cough, bronchitis, catarrhs, asthma, various types of haemoptysis, tonsilitis, pharyngitis, hoarseness, sore throat, influenza, croup, whooping cough, nervous cough of children, lung diseases such as pneumonia and pulmonary phthisis, nervous stomach and intestinal cramps, gastritis, gastro-enteralgia, headaches coming from a pathological disorder of the stomach, cough that follows or comes with inflammatory skin diseases such as: the measles, scarlet fever, small pox, erysipelas, and so on, prolonged diseases with irritation and weakening, and some skin diseases'.

Singer finds them to be very active aids against several alterations of the voice. The same year, 1855, the author adds onto the first report with a second one where several physicians or patients testify to the efficacy of such preparations (11). Dorvault also mentioned Dr Chrestien, from Montpellier (France), who explains, concerning snail paste from Mure's company (based in Pont St Esprit, Gard, France): 'During the 50 years that I have practiced medicine, I have not found a remedy more efficient than snails against chest irritations' (9). During the same time, the Bouchardat formulary (another reference book at that time) mentioned Figuier snail paste and Chrestien snails (12). The encyclopaedic dictionary for medical sciences in 1886 describes this therapeutic usage of helix and adds: 'One still makes a saccharum with a snail species commonly called littorine or sea snail, that was previously related to the Helix genus now known as Littorina littorea $\mathrm{L}$. One keeps this preparation in a well sealed bottle' (13). However, this interest in snails did not stop at the end of the 19th century.

\section{0th Century: Therapeutic and Biological Properties of Snails are Confirmed}

The 1945 edition of Dorvault still devotes an entire paragraph to snails, indicating that the therapeutic usage of snails was still alive. Although one could think that this was the end of the medical career of snails, this was indeed not the case, since several scientific articles re-launched the subject once again. In France, Quevauviller prepared a relatively exhaustive review of snail therapeutic properties in 1953 and related the use of snail syrup in the 1920s for patients with chronic bronchitis (14). The author emphasized that 'if no one even thinks about using such a therapy for tuberculosis, recent research has confirmed the sedative properties of several formulations based on Helix pomatia for whooping cough and chronic bronchitis, related to the antispasmodic and fluidizing properties of the secretions'. For the first time, the actual preparation 
of the product is described: 'One can find presently several extracts of mucus (helicidine, pertussidine, pomaticine) that differ from each other only by their production processes. Most often, one soaks the snails with $1 \%$ ww of sodium chloride. Mucus is then collected, settled, filtrated, concentrated and then dried according to various processes, either at low temperature under vacuum evaporation, or freeze dried or spray dried. The resulting aqueous solutions can then be retained aseptically within sterile vials after filtration through specific filters, or by adding antiseptic substances, the most used being glycerine. The various chemical components of Helix can also be analysed using enzyme procedures thus revealing: more than 30 enzymes within the digestive mucus and several enzymes within the pancreostomach, the muscle, and lymphatic fluid'.

Quevauviller then also reviewed the pharmacological activities of H.pomatia mucus: in vitro mucolytic activity, its inhibiting effect on Brolet and Gaugon bacteria and spasmolytic activity in the respiratory tract. The author concluded that 'the antispasmodic activities of Helix mucus on the bronchial tree can been observed only at high doses, far from any therapeutic doses. We then do not consider that this musculotropic effect could explain the sedation that results from fits of whooping cough. It is most probably the previously described mucolytic and bacteriolytic properties that are responsible for the clinical observations.' The author establishes a link with the therapeutic usage of gastric and intestinal pork mucins 'which are still used in therapy' (14). This usage is actually described by Monceaux in $1933(21,22)$.

\section{Current Concerns: Snails Enter the Present, Yielding More Possibilities and a New Drug now Under Testing by the FDA}

In 1999, Pons et al. demonstrated that the broncho-relaxant effect of helicidine was related to the release of $E_{2}$ prostaglandins and inhibited by pre-treatment with indomethacine, a cyclooxygenase inhibitor (15). The authors concluded that the effect of H.pomatia extract on the trachea is partially related to the release of a relaxant prostanoïd, $\mathrm{E}_{2}$ prostaglandin, but its cellular origin within the pulmonary tract remains to be determined. Other scientists are interested in the role of H.pomatia in medicine. From the common snail, there is a lectin called Helix pomatia agglutinin (HPA) that is used as a prognostic indicator for some cancers, such as those of the breast, stomach and colon. HPA fixation on histological preparations of these tissues is associated with an ominous prognosis, indicating that HPA-associated glycoproteins are linked to metastasis of cancers $(16,17)$.

Investigators have also examined the life expectancy of populations that eat snails. A comparative study has been performed in seven different countries, revealing that there were 20 times fewer deaths related to cardiovascular diseases in Crete compared with the USA. Among the proposed explanations, one can observe that people from Crete eat large quantities of snails. 'Everyone picks them up in the fields, under stones. They are found during the summer on olive trees. Analyses indicate that these snails are different from others. They are rich in a fatty acid derived from the natural herbs that they eat. The most famous is the so called pourprier' (18). Actually, this is $\alpha$-linolenic acid that has been reported to have a protective effect against cardiovascular diseases. Recent studies published in 2001 showed that $\alpha$-linolenic acid prevents ventricular fibrillation and reduces platelet aggregation (19). The FDA has also shown interest in snails. In the 1980s, American investigators from the University of Utah evaluated hundreds of neurotoxins derived from sea snails. These are utilized as they attack their prey or their predators and induce a neuro-muscular blockage. This is why ziconotide (SNXIII), a synthetic peptide derived from snail venom, has been under FDA review since 1999. Pre-clinical and clinical studies of this new drug indicate a powerful anesthetic effect. During controlled clinical trials, ziconotide reduced pain intensity by $53 \%$ (compared with $18 \%$ for the placebo), even in patients insensitive to morphine (20). In 2000, a new neurotoxin, so-called conotoxin TVIIA, was extracted from Conus tulipa, a fish-eating sea snail. Finally, in 2001, another peptide, the so-called contryphan- $\mathrm{Vn}$, was extracted from the venom of a Mediterranean snail (24).

\section{Conclusions: Implications of Snails for CAM}

This brief historical review concerning the therapeutic use of snails reveals that from antiquity to the present, humans have always considered snails as a source of surprising and numerous therapeutic or biological properties. Besides snailbased empirical formulations, a certain measure of true scientific investigation has been performed, especially including the components of the respiratory system including the bronchial tree and trachea. Thus novel avenues are opening up via new information on cardiovascular diseases but also via sea snails for pain treatment, yet another approach. The anesthetic properties of sea Conus neuropeptides are promising, thus paving the way for discoveries of linkages to the nervous system.

\section{References}

1. Cranga F, Cranga Y. L'Escargot: Zoologie, Symbolique, Imaginaire, Médecine et Gastronomie. du Bien Public, Dijon, 1991.

2. Reutter. Des remèdes d'origine humaine et animale prescrits au temps des Romains en Europe. Revue d'Historie de la Pharmacie 1915;12:179.

3. Reuitter. Des remèdes d'origines humaine et animale prescrits au temps des Romains en Europe. Revue d'Historie de la Pharmacie 1916;13:201.

4. Thomas de Cantimpré. Liber de Natura Rerum 9:45. 1973, New York.

5. Cadard J. Les Escargots (Hélix pomatia L. et Hélix aspersa M.) Biologie. Elevage. Parcage. Histoire. Gastronomie. Commerce. 1955; Ed. Paul Lechevalier. Libraire Pour Les Science Natwelles, Paris.

6. Lemery N. Pharmacopée Universelle. Charles Maurice d'Houry, Paris, 1738, 757-8.

7. Julien P, Charroppin P. L'escargot contre la hernie? RHP 1983;258:215-9. 1983.

8. Figuier O. Mémoire sur la Composition Chimique des Escargots et sur les Préparations Pharmaceutiques dont ils sont la Base. F. Gelly, Montpellier, 1840

9. Dorvault. L'officine, 1877.

10. Baron-Barthelemy M. Mémoire sur les Préparations à Base d'Hélicine Admises à l'Exposition Universelle de 1855. Sirop et Bonbons Héliciés. De Bailly, Divry et Cie, Paris, 1855. 
11. Baron-Barthelemy M. Sirop et Bonbons Héliciés, Pectoraux, Mucilagineux, Lénitifs et Antiphlogistiques. Paris, 1855. C Bortrard Beziers, France.

12. Bouchardat Formulaire. 1878.

13. Dechambr A, Lereboullet L. Dictionnaire Encyclopédique des Sciences Médicales. Masson, Paris, 1886, 12:4.

14. Quevauviller A, Mainil J, Garcet S. Le mucus d'Hélix pomatia L. Préparation, composition, propriétés thérapeutiques et pharmacodynamiques. Rev Pathol Gen Comp 1953;653:1514-38.

15. Pons F, Koenig M, Michelot R et al. L'effet bronchorelaxant de l'hélicidine, un extrait d'Hélix pomatia, fait intervenir une libération de prostaglandine E2. Pathol Biol 1999;47:73-80.

16. Dwek MV, Ross HA, Streets AJ et al. Helix pomatia agglutinin lectinbinding oligosaccharides of aggressive breast cancer. Int J Cancer 2001; 95:79-85.

17. Brooks SA, Leathem AJ. Prediction of lymph node involvement in breast cancer by detection of altered glycosylation in the primary tumour. Lancet 1991;38:71-4.
18. Labonne G. Crête Aujourd'hui. No. 2.

19. Lanzman-Petitthory D. Alpha-linolenic acid and cardiovascular diseases. J Nutr Health Aging 2001;5:179-83.

20. Webster L, Henderson R, Katz N, Ellis D. Characterization of confusion, an adverse event associated with intrathecal ziconotide infusion in chronic pain patients. Pain Med 2001;2:253-4.

21. Onceaux RH, Fontaine R. Le mucus gastrique et son rôle protecteur. $L a$ Presse Médicale 1933;46.

22. Monceaux RH Le pouvoir protecteur des mucines et son importance en gastro-entérologie. Arch Mal Appareil Dig 1933;223:4a.

23. Dorvault. L'officine, 1945.

24. Massilia G, Schinina ME Ascenzi P et al. Contryphan-Vn: a novel peptide from the venom of Mediterranean snail Conus ventricosus. Biochem Biophys Res Commun 2001;288:908-13.

Received October 12, 2004; revised November 16, 2004; accepted December 24, 2004 


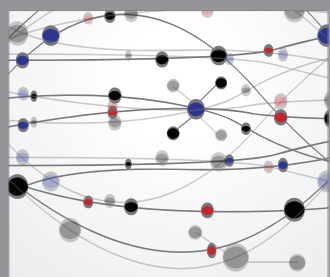

The Scientific World Journal
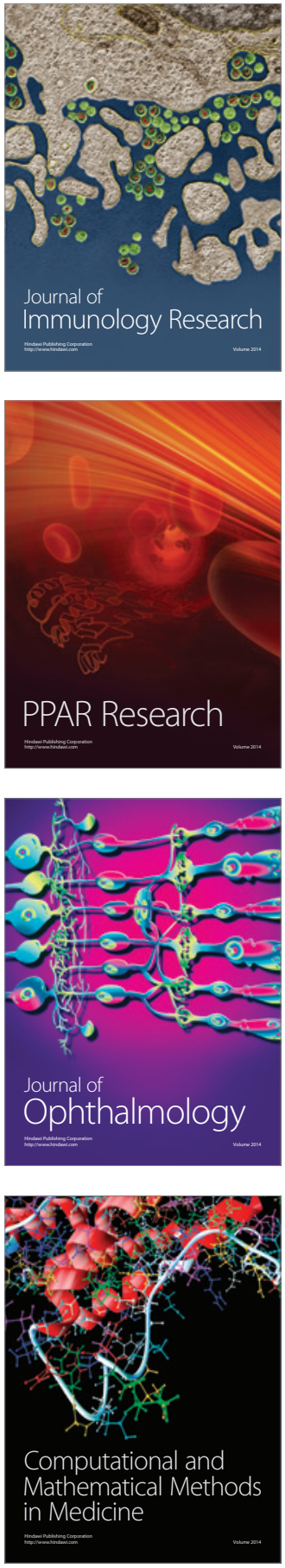

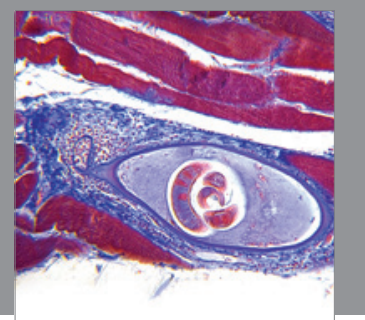

Gastroenterology

Research and Practice
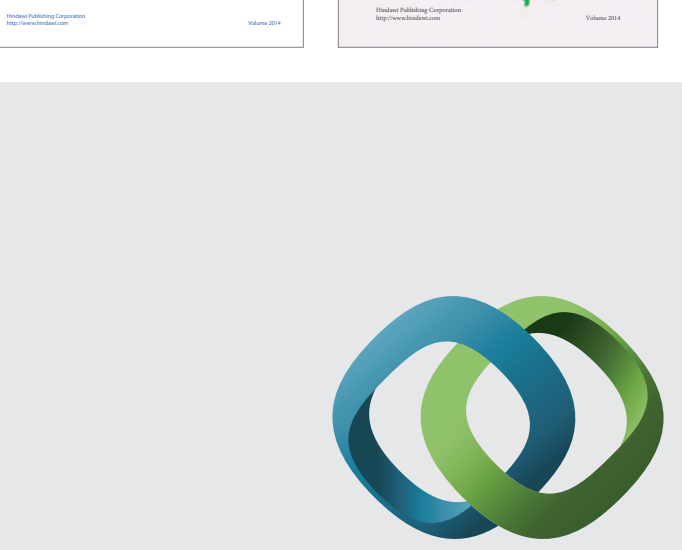

\section{Hindawi}

Submit your manuscripts at

http://www.hindawi.com
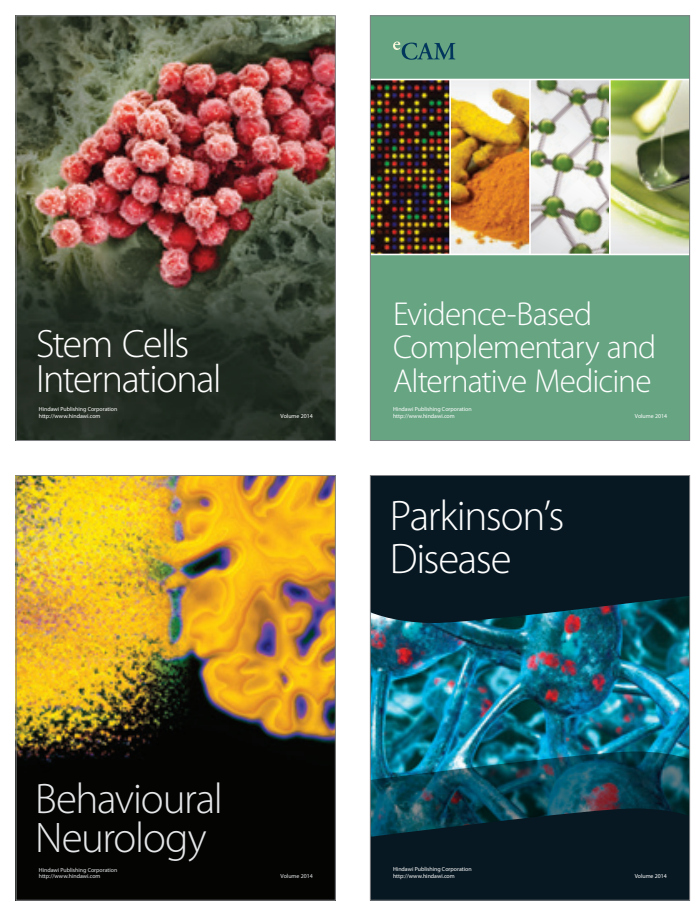

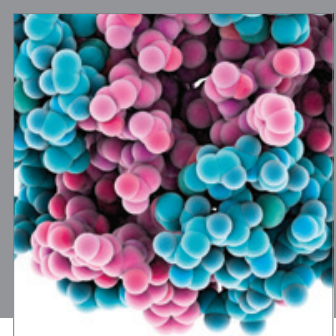

Journal of
Diabetes Research

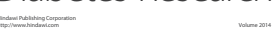

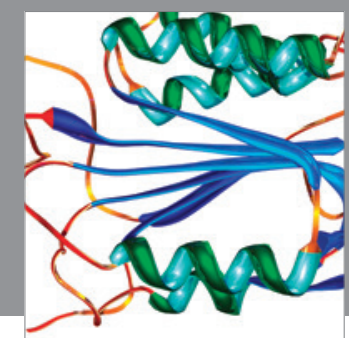

Disease Markers
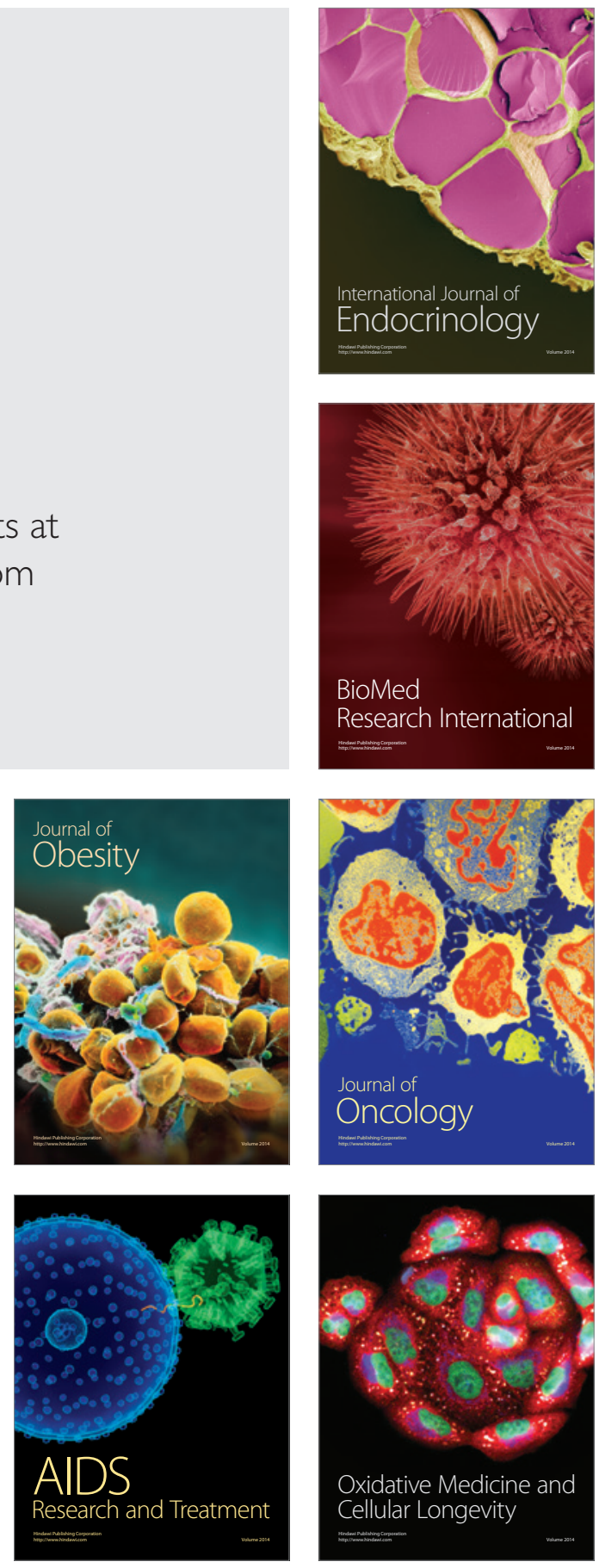